\title{
PENGARUH MODEL PEMBELAJARAN DAN GAYA BELAJAR TERHADAP HASIL BELAJAR MAHASISWA PADA MATAKULIAH POLA KERAH
}

\author{
Soelistyowati \\ (Email: soelistyowati@ciputra.ac.id) \\ Visual Communication Design \\ Fakultas Industri Kreatif \\ Universitas Ciputra \\ UC Town, Citraland Surabaya 60219
}

\begin{abstract}
ABSTRAK
Penelitian ini bertujuan untuk memperoleh informasi tentang perbedaan hasil belajar, antara mahasiswa yang belajar dengan model pembelajaran berdasarkan masalah dan model pembelajaran langsung pada kompetensi membuat pola kerah, memperoleh informasi tentang perbedaan hasil belajar, antara mahasiswa yang memiliki gaya belajar visual, auditorial dan kinestetik pada kompetensi membuat pola kerah, memperoleh informasi tentang interaksi antara model pembelajaran dan gaya belajar terhadap hasil belajar mahasiswa pada kompetensi membuat pola kerah. Desain penelitian yang digunakan dalam penelitian ini adalah Factorial Design. Sampel kelas yang digunakan dalam penelitian ini adalah kelas A dan B di Universitas Ciputra Surabaya tahun ajaran 2016/2017. Analisis data menggunakan Analysis of Varians (ANOVA) dengan taraf signifikan 0,05 menjadi 0,010 signifikan 2.871.403. Penelitian menemukan bahwa hasil belajar mahasiswa yang belajar menggunakan model pembelajaran berdasarkan masalah, lebih tinggi secara signifikan dibanding hasil belajar mahasiswa yang belajar dengan model pembelajaran langsung pada kompetensi membuat pola kerah. Hasil belajar mahasiswa yang memiliki gaya belajar visual, lebih tinggi secara signifikan dibanding hasil belajar mahasiswa yang memiliki gaya belajar auditorial dan kinestetik pada kompetensi membuat pola kerah. Terdapat interaksi antara model pembelajaran dan gaya belajar terhadap hasil belajar pada mata kuliah produksi fesyen membuat pola kerah.
\end{abstract}

Kata Kunci: gaya belajar; hasil belajar; model pembelajaran; pembelajaran langsung

\section{ABSTRACT}

This study aims to get information about the differences in learning outcomes among students who study use the problem-based learning and direct learning on the basis of competence collar pattern making, getting information about the differences in learning outcomes, the students has a learning style of visual, auditory and kinesthetic on the basis of competence collar pattern making, getting information about the interaction between learning models and learning styles to learning outcomes in basic competencies collar pattern making. The research design in this study used a Factorial Design. The sample classes used in this study was a class $A$ and B Universitas Ciputra Surabaya academic year 2016/2017. Analysis of data using Analysis of Variance (ANOVA) with a significant level of 0,05 to 0,010 significant 2.871.403. This research found that learningoutcomes of students who study use the problem-based learning was significantly higher than the students who study use the direct learning on the basis of competence collar pattern making. Learning outcomes of the students have a learning style of visual was significantly higher than the students has a learning style of auditory and kinesthetic on the basis of competence collar pattern making. There was an interaction between learning models and learning styles to learning outcomes in basic competencies fashion production collar pattern making. 


\section{PENDAHULUAN}

Pembelajaran yang baik diperlukan pemahaman konsep yang baik pula. Pentingnya pemahaman konsep dalam proses belajar mengajar sangat mempengaruhi sikap, keputusan, dan cara-cara memecahkan masalah. Pemahaman yang dimaksud adalah pemahaman siswa terhadap fakta-fakta yang saling berkaitan dengan kemampuannya untuk menggunakan pengetahuan tersebut dalam situasi baru (Trianto, 2007: 65).

Dosen memiliki peran dalam mencetak peserta didik yang berkualitas, seperti memberikan layanan pembelajaran yang sesuai dengan situasi dan kondisi, serta menyenangkan bagi peserta didik. Salah satu bentuk layanan tersebut berupa cara mengajar, strategi pembelajaran yang digunakan, sarana dan prasarana yang digunakan, model pembelajaran, serta metode pembelajaran yang digunakan dalam proses pembelajaran (Sujarwo, 2010).

Menurut Trianto (2007: 66), permasalahan dalam pembelajaran saat ini adalah menemukan cara yang terbaik untuk menyampaikan berbagai konsep yang diajarkan guru, sehingga siswa dapat mengingat konsep tersebut lebih lama dan mengaplikasikannya dalam kehidupan nyata. Model pembelajaran yang sesuai dengan permasalahan tersebut salah satunya adalah model pembelajaran berdasarkan masalah. Pada model pembelajaran berdasarkan masalah, pembelajarannya dikendalikan oleh masalah sehingga siswa terbiasa dimulai dengan memecahkan masalah dan kemudian diajukan untuk memperoleh pengetahuan yang baru (Kosasih, 2014:74). Hal ini akan membuat mahasiswa tidak hanya mempelajari konsep dasar pola secara hafalan tanpa makna tetapi juga pemahaman secara individual, sehingga mempelajari konsep dasar pola kerah tidak harus dihafalkan melainkan mereka akan berusaha untuk menemukan dan memahami konsep membuat pola kerah sehingga mahasiswa dapat memahami kompetensi membuat pola kerah secara bermakna. Jadi, dapat dikatakan bahwa dengan suatu model yang berdasarkan masalah akan memudahkan mahasiswa dalam menemukan konsep dari suatu materi.

Hasil obsevasi melalui wawancara dengan dosen Universitas Ciputra Surabaya diketahui bahwa model pembelajaran yang selama ini digunakan dalam mata kuliah dasar pola adalah model pembelajaran langsung. Model pembelajaran langsung sesuai diterapkan 
untuk materi praktik, namun dalam proses pembelajarannya peran dosen masih lebih dominan daripada peran mahasiswa (teacher centered). Berdasarkan pengamatan peneliti pada saat pembelajaran di kelas, aktivitas mahasiswa cenderung rendah, seperti kurang berani mengemukakan pendapat, mengajukan pertanyaan, kurang berani bereksperimen dan cenderung menunggu instruksi dari dosen.

\section{PEMBAHASAN}

Model pembelajaran langsung adalah salah satu pendekatan mengajar untuk menunjang proses belajar mengajar siswa yang berkaitan dengan pengetahuan deklaratif dan pengetahuan prosedural yang diajarkan dengan selangkah demi selangkah (Nur, 2008: 23). Pada model pembelajaran langsung mahasiswa cenderung menirukan yang telah diajarkan oleh dosen, sehingga keterampilan mahasiswa dalam memecahkan masalah kurang, dan apabila mahasiswa diberikan desain baru untuk dibuat pecah pola, akan mengalami kesulitan.

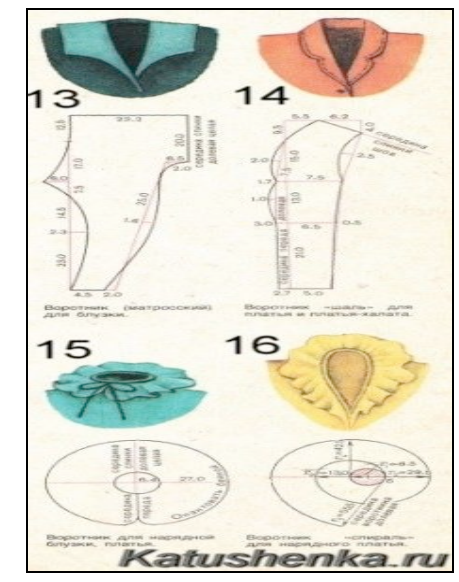

Gambar 1. Contoh Macam-macam dasar kerah http://www.pintrest.com

Dalam dasar pola terdapat matakuliah fesyen produksi yang membahas membuat pola kerah. Pada materi membuat pola kerah, yang ingin dicapai adalah mahasiswa dapat memahami dan menguasai pengetahuan tentang pengertian kerah, mengidentifikasi kerah berdasarkan bentuk, mengidentifikasi kerah berdasarkan pemasangan serta terampil membuat pola kerah dasar maupun pada berbagai macam desain. Pada materi ini terdapat banyak masalah yang harus dipecahkan supaya mahasiswa dapat menerapkan pecah pola kerah dalam berbagai model busana. 
Model pembelajaran yang diterapkan diharapkan merupakan suatu cara yang menarik dan dapat memacu keaktifan dan keterampilan mahasiswa. Model pembelajaran yang dapat digunakan dalam pembelajaran membuat pola kerah adalah model pembelajaran berdasarkan masalah. Model pembelajaran ini akan diterapkan, dengan tujuan untuk membuat mahasiswa lebih aktif dan mampu memecahkan masalah yang ada dalam membuat pola kerah. Menurut Tan (Rusman, 2010:229), pada model pembelajaran berdasarkan masalah, kemampuan berpikir mahasiswa betul-betul dioptimalisasikan melalui proses kerja kelompok atau tim yang sistematis, sehingga mahasiswa dapat memberdayakan, mengasah, menguji, dan mengembangkan kemampuan berpikirnya secara berkesinambungan dalam membuat pola kerah.

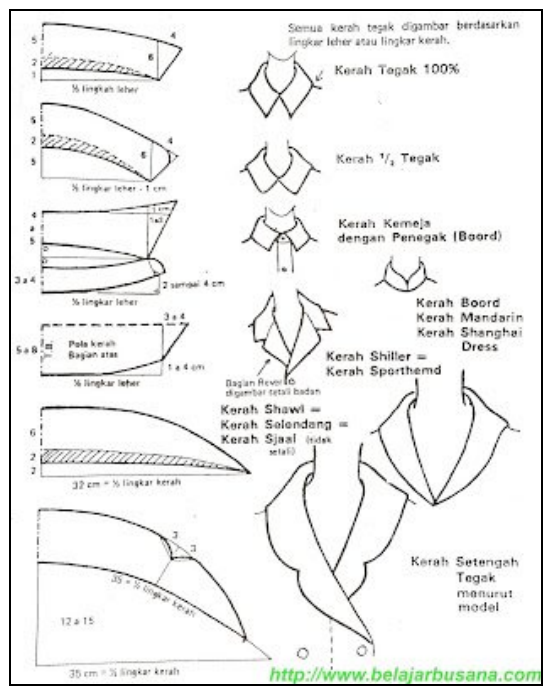

Gambar 3. Contoh Macam-macam pola kerah dasar Sumber http://www.pintrest.com

Selain model pembelajaran, faktor lain yang mempengaruhi keberhasilan suatu proses pembelajaran adalah mahasiswa sendiri. Menurut Sardiman (2013: 139), pada diri siswa mempunyai karakteristik yang dapat mempengaruhi kegiatan belajar siswa antara lain, latar belakang pengetahuan dan taraf pengetahuan, motivasi belajar, gaya belajar, kemampuan awal, lingkungan sosial ekonomi, kecerdasan, dan lain-lain. Terkait dengan gaya belajar, gaya belajar merupakan cara belajar mahasiswa yang lebih disukai dalam melakukan kegiatan berpikir, memproses dan mengerti suatu informasi. Masing-masing mahasiswa memiliki gaya belajar yang tidak sama satu dengan yang lainnya. Pada dasarnya, anak akan belajar sesuai dengan gaya belajarnya, dan setiap gaya belajar berpengaruh pada hasil belajar mereka. Menurut Kolb (Nurlaela, 2010:39), jika anak 
bertemu dengan lingkungan belajar yang tidak sesuai dengan gaya belajarnya, maka anak akan menolak lingkungan belajar itu. Jadi, dapat dikatakan bahwa gaya belajar berpengaruh terhadap hasil belajar mahasiswa.

Menurut Gunawan (2003: 139), murid yang belajar dengan gaya belajar mereka sendiri saat mengerjakan tes, akan mencapai nilai yang jauh lebih tinggi dibandingkan bila mereka belajar dengan cara yang tidak sejalan dengan gaya belajar mereka. Pendapat ini diperkuat dengan hasil penelitian yang dilakukan oleh Hariadi (2013) yang menyimpulkan bahwa gaya belajar berpengaruh positif terhadap prestasi belajar

Hasil belajar merupakan indikator keberhasilan dalam suatu pembelajaran. Dalam proses pembelajaran, hasil belajar yang dicapai mahasiswa perlu diketahui oleh dosen, agar dosen dapat merencanakan atau mendesain pembelajaran secara tepat. Hasil belajar diklasifikasikan oleh Bloom yang membaginya menjadi tiga ranah, yakni ranah kognitif, ranah afektif, dan ranah psikomotor (Ibrahim, 2010: 103). Pada materi membuat pola kerah dosen akan menerapkan model pembelajaran berdasarkan masalah di kelas A dan model pembelajaran langsung di kelas $\mathrm{B}$.

Terkait dengan hal tersebut, beberapa penelitian menunjukkan bahwa model pembelajaran berdasarkan masalah dapat meningkatkan hasil belajar baik pada mahasiswa. Menurut penelitian Wulandari (2013), Nafiah (2013), McParland, et.al (2004), Sungur dan Ceren (2006), dan Fadly (2012) bahwa penerapan model pembelajaran berdasarkan masalah berpengaruh positif dan signifikan terhadap hasil belajar siswa. Berdasarkan uraian di atas dapat disimpulkan bahwa masalah dalam pembelajaran matakuliah membuat pola kerah adalah masih rendahnya hasil belajar mahasiswa. Penerapan model pembelajaran berdasarkan masalah diharapkan dapat mengatasi masalah tersebut. Gaya belajar juga akan dikaji sebagai faktor yang diharapkan dapat meningkatkan hasil belajar mahasiswa.

\section{METODE PENELITIAN}

Penelitian ini merupakan penelitian eksperimen semu dengan menggunakan pendekatan kuantitatif. Desain penelitian yang digunalan dalam penelitian ini adalah Factorial Design (Tuckman, 1988). Penelitian ini melibatkan 2 kelompok subjek. Kelompok eksperimen 
mendapat perlakuan dengan model pembelajaran berdasarkan masalah, dan kelompok kontrol mendapat perlakuan dengan model pembelajaran langsung. Pada awal pembelajaran, kedua kelompok mendapat tes kemampuan awal (pre-test) untuk mengetahui apakah kedua kelompok tersebut memiliki kemampuan yang sama.

Variabel bebas adalah model pembelajaran yang dibedakan menjadi 2, yaitu: model pembelajaran berdasarkan masalah dan model pembelajaran langsung. Variabel terikat adalah hasil belajar. Variabel moderator adalah gaya belajar mahasiswa. Gaya belajar dibedakan menjadi 3, yaitu: visual, auditorial dan kinestetik. Desain penelitian sebagai berikut:

Tabel 1. Desain penelitian

\begin{tabular}{|ccccc|}
\hline Eksperimen & $\mathrm{O}_{1}$ & $\mathrm{X}_{1}$ & $\mathrm{Y}_{1}$ & $\mathrm{O}_{2}$ \\
& $\mathrm{O}_{3}$ & $\mathrm{X}_{1}$ & $\mathrm{Y}_{2}$ & $\mathrm{O}_{4}$ \\
& $\mathrm{O}_{5}$ & $\mathrm{X}_{1}$ & $\mathrm{Y}_{3}$ & $\mathrm{O}_{6}$ \\
\hline Kontrol & $\mathrm{O}_{7}$ & $\mathrm{X}_{2}$ & $\mathrm{Y}_{1}$ & $\mathrm{O}_{8}$ \\
& $\mathrm{O}_{9}$ & $\mathrm{X}_{2}$ & $\mathrm{Y}_{2}$ & $\mathrm{O}_{10}$ \\
& $\mathrm{O}_{11}$ & $\mathrm{X}_{2}$ & $\mathrm{Y}_{3}$ & $\mathrm{O}_{12}$ \\
& &
\end{tabular}

(Diadaptasi dari: Tuckman, 1988: 155)

Keterangan:

X1: perlakuan menggunakan Model Pembelajaran Berdasarkan Masalah

X2: perlakuan menggunakan Model Pembelajaran Langsung

$\mathrm{O} 1=\mathrm{O}_{3}=\mathrm{O}_{5}$ : Pre-test kelas eksperimen

$\mathrm{O}_{2}=\mathrm{O}_{4}=\mathrm{O}_{6}$ : post-test kelas eksperimen

Y1: variabel moderator gaya belajar visual

Y2: variabel moderator gaya belajar auditorial

Y3: variabel moderator gaya belajar kinestetik

$\mathrm{O}_{7}=\mathrm{O}_{9}=\mathrm{O}_{11}$ : Pre-test kelas kontrol

$\mathrm{O}_{8}=\mathrm{O}_{10}=\mathrm{O}_{12}:$ post-test kelas kontrol

Rangkuman hasil analisis penelitian akan disajikan dalam bentuk tabel 2 seperti berikut:

Tabel 2. Desain Analisis Penelitian

\begin{tabular}{|l|l|l|}
\hline \multirow{2}{*}{ Gaya Belajar (Y) } & \multicolumn{2}{|l|}{ Model Pembelajaran (X) } \\
\cline { 2 - 3 } & MPBM (X1) & MPL(X2) \\
\hline Visual $\left(\mathrm{Y}_{\mathrm{v}}\right)$ & $\mathrm{Y}_{\mathrm{v}} \mathrm{X}_{1}$ & $\mathrm{Y}_{\mathrm{v}} \mathrm{X}_{2}$ \\
\hline Auditorial $\left(\mathrm{Y}_{\mathrm{a}}\right)$ & $\mathrm{Y}_{\mathrm{a}} \mathrm{X}_{1}$ & $\mathrm{Y}_{\mathrm{a}} \mathrm{X}_{2}$ \\
\hline Kinestetik $\left(\mathrm{Y}_{\mathrm{k}}\right)$ & $\mathrm{Y}_{\mathrm{k}} \mathrm{X}_{1}$ & $\mathrm{Y}_{\mathrm{k}} \mathrm{X}_{2}$ \\
\hline
\end{tabular}


Keterangan :

$\mathrm{Y}_{\mathrm{v}} \mathrm{X}_{1}=$ Hasil belajar mahasiswa dengan menggunakan MPBM pada mahasiswa dengan gaya belajar visual

$\mathrm{Y}_{\mathrm{v}} \mathrm{X}_{2}=$ Hasil belajar mahasiswa dengan menggunakan MPL pada mahasiswa dengan gaya belajar visual

$\mathrm{Y}_{\mathrm{a}} \mathrm{X}_{1}=$ Hasil belajar mahasiswa dengan menggunakan MPBP pada mahasiswa dengan gaya belajar auditorial

$\mathrm{Y}_{\mathrm{a}} \mathrm{X}_{2}=$ Hasil belajar mahasiswa dengan menggunakan MPL pada mahasiswa dengan gaya belajar auditorial

$\mathrm{Y}_{\mathrm{k}} \mathrm{X}_{1}=$ Hasil belajar mahasiswa dengan menggunakan MPBP pada mahasiswa dengan gaya belajar kinestetik

$\mathrm{Y}_{\mathrm{k}} \mathrm{X}_{2}=$ Hasil belajar mahasiswa dengan menggunakan MPL pada mahasiswa dengan gaya belajar kinestetik

Populasi dalam penelitian ini adalah mahasiswa Desain Komunikasi Visual alur studi fesyen desain di Universitas Ciputra Surabaya tahun pelajaran 2016/2017. Sampel terdiri dari dua kelompok yaitu kelompok eksperimen kelas A sejumlah 33 mahasiswa dan kelompok kontrol kelas B sejumlah 34 mahasiswa.

Teknik analisis data menggunakan uji asumsi dan uji hipotesis. Uji asumsi terdiri dari uji normalitas dan uji homogenitas. Uji normalitas data, diuji dengan uji kolmogorov-smirnov dengan menggunakan taraf signifikansi 0,05 (Kadir 2015: 155). Data dinyatakan berdistribusi normal jika signifikansi lebih besar dari 5\% atau 0,05 dan pengolahan data menggunakan SPSS 16. Uji homogenitas dalam penelitian ini menggunakan aplikasi SPSS. Cara pengambilan keputusan untuk uji homogenitas ini dengan melihat pada nilai $p$-value pada tabel. Jika $p$-value $>0,05$ maka data homogen, jika $p$-value $<0,05$ maka data tidak homogen. Uji hipotesis penelitian ini menggunakan Analysis of Varians (ANOVA) untuk melakukan pengujian terhadap hipotesis yang menyatakan ada pengaruh penggunaan model pembelajaran, gaya belajar mahasiswa, serta interaksi antara model pembelajaran dan gaya belajar yang signifikan terhadap hasil belajar membuat pola kerah.

\section{HASIL UJI NORMALITAS}

Hasil pengujian uji normalitas adalah data terdistribusi normal dengan nilai signifikan pada kelas eksperimen 0,174 dan kelas control 0,052. Sedangkan hasil pengujian uji 
homogenitas adalah varian kelompok data sama dengan nilai signifikan 0,586. Hasil Pengujian Mean Hasil Belajar mahasiswa Atas Pengaruh Model Pembelajaran dapat dilihat pada Tabel 3:

Tabel 3. Hasil Belajar 1

\begin{tabular}{|c|c|c|c|c|}
\hline \multicolumn{5}{|c|}{ Dependent Variable: Nilai Hasil Belajar } \\
\hline \multirow[b]{2}{*}{ Model } & \multirow[b]{2}{*}{ Mean } & \multirow[b]{2}{*}{$\begin{array}{l}\text { Std. } \\
\text { Error }\end{array}$} & \multicolumn{2}{|c|}{ 95\% Confidence Interval } \\
\hline & & & $\begin{array}{l}\text { Lower } \\
\text { Bound }\end{array}$ & Upper Bound \\
\hline MPBM & 81.571 & .917 & 79.738 & 83.404 \\
\hline MPL & 77.128 & .856 & 75.417 & 78.839 \\
\hline
\end{tabular}

Hasil Pengujian Mean Hasil Belajar Mahasiswa Atas Pengaruh Gaya Belajar dapat dilihat pada Tabel 4 berikut:

Tabel 4. Hasil Belajar 2

\begin{tabular}{|l|l|l|l|l|}
\hline \multicolumn{1}{|l|}{ Dependent Variable: Nilai Hasil Belajar } \\
\hline & & & \multicolumn{3}{l|}{$\begin{array}{l}\text { 95\% } \\
\text { Interval }\end{array}$} \\
\cline { 4 - 5 } & & & Confidence \\
\cline { 4 - 5 } & & Std. & Lower & Upper \\
Gaya Belajar & Mean & Error & Bound & Bound \\
\hline Visual & 83.135 & .908 & 81.320 & 84.949 \\
Kuditorial & 75.333 & 1.313 & 72.709 & 77.958 \\
\hline
\end{tabular}

Selanjutnya hasil analisis data dengan Anava dapat dilihat pada Tabel 3. Hipotesis nol (Ho) ditolak jika $p<0,05$. Berdasarkan tabel tersebut, maka dapat dideskripsikan hasil pengujian hipotesis dengan taraf signifikansi 5\%, diperoleh: (1) $\mathrm{F}=12.550$ dan angka signifikansi $p=0,001$, berati bahwa hasil belajar menunjukkan perbedaan yang signifikan di antara variasi model pembelajaran, (2) $F=12.292$ dan angka signifikansi $p=0,000$, berarti bahwa 
hasil belajar menunjukkan perbedaan yang signifikan di antara variasi gaya belajar, (3) F = 4.988 dan angka signifikansi $p=0,010$, berarti hasil belajar dipengaruhi oleh adanya interaksi antara model pembelajaran dengan gaya belajar siswa,

Tabel 5. Ringkasan Hasil Anava

\begin{tabular}{|l|l|l|l|l|l|}
\hline \multicolumn{5}{|l|}{ Tests of Between-Subjects Effects } \\
Dependent Variabel: Nilai Hasil Belajar \\
\hline Source & $\begin{array}{l}\text { Type III Sum } \\
\text { of Squares }\end{array}$ & Df & $\begin{array}{l}\text { Mean } \\
\text { Square }\end{array}$ & F & Sig. \\
\hline Corrected & $1429.958^{\mathrm{a}}$ & 5 & 285.992 & 12.103 & .000 \\
Model & 378460.19 & 1 & 378460.19 & $1.602 \mathrm{E} 4$ & .000 \\
Intercept & 580.930 & 2 & 290.465 & 12.292 & .000 \\
Godel & 296.570 & 1 & 296.570 & 12.550 & .001 \\
GB ${ }^{*}$ Model & 235.741 & 2 & 117.870 & 4.988 & .010 \\
Error & 1441.445 & 61 & 23.630 & & \\
Total & 435520.00 & 67 & & & \\
Corrected & 2871.403 & 66 & & & \\
Total & & & & & \\
\hline
\end{tabular}

Berdasarkan hasil pengujian hipotesis penelitian di antaranya diperoleh bukti bahwa hasil belajar mahasiswa yang mengikuti pembelajaran dengan model pembelajaran berdasarkan masalah berbeda secara signifikan dengan hasil belajar mahasiswa yang mengikuti pembelajaran dengan model langsung. Hasil analisis deskriptif menunjukkan bahwa rerata hasil belajar mahasiswa yang mengikuti pembelajaran dengan model pembelajaran berdasarkan masalah lebih tinggi daripada hasil belajar siswa yang belajar dengan model pembelajaran langsung. Hal ini membuktikan bahwa pembelajaran berdasarkan masalah secara signifikan berpengaruh lebih tinggi terhadap pencapaian hasil belajar dibandingkan dengan model pembelajaran langsung. Hasil penelitian ini sejalan dengan penelitian terdahulu yang dilakukan oleh Wulandari (2013), Nafiah (2014), McParland (2004), Sungur dan Tekkaya (2006), yang menunjukkan keunggulan pembelajaran berdasarkan masalah. 
Selanjutnya, hasil analisis deskriptif menunjukkan bahwa hasil belajar mahasiswa yang memiliki gaya belajar visual, lebih tinggi secara signifikan dibanding hasil belajar bagi mahasiswa yang memiliki gaya belajar auditorial maupun mahasiswa yang memiliki gaya belajar kinestetik pada mata kuliah membuat pola kerah. Pengujian hipotesis ini sejalan dengan penelitian yang dilakukan oleh Rachmawati (2013), hasil belajar mahasiswa yang menggunakan gaya belajar visual lebih baik dibandingkan dengan gaya belajar kinestetik dan auditorial. Pengujian hipotesis ini juga sejalan dengan penelitian yang dilakukan oleh Chen dan Hua-Huei (2014), yang menyimpulkan bahwa gaya belajar berpengaruh positif terhadap prestasi belajar mahasiswa.

Berdasarkan pengujian hipotesis, diketahui bahwa hasil belajar dipengaruhi oleh adanya interaksi antara model pembelajaran dengan gaya belajar mahasiswa. Berdasarkan Gambar 1, tampak pola interaksi hasil belajar mahasiswa atas pengaruh model pembelajran dan gaya belajar.

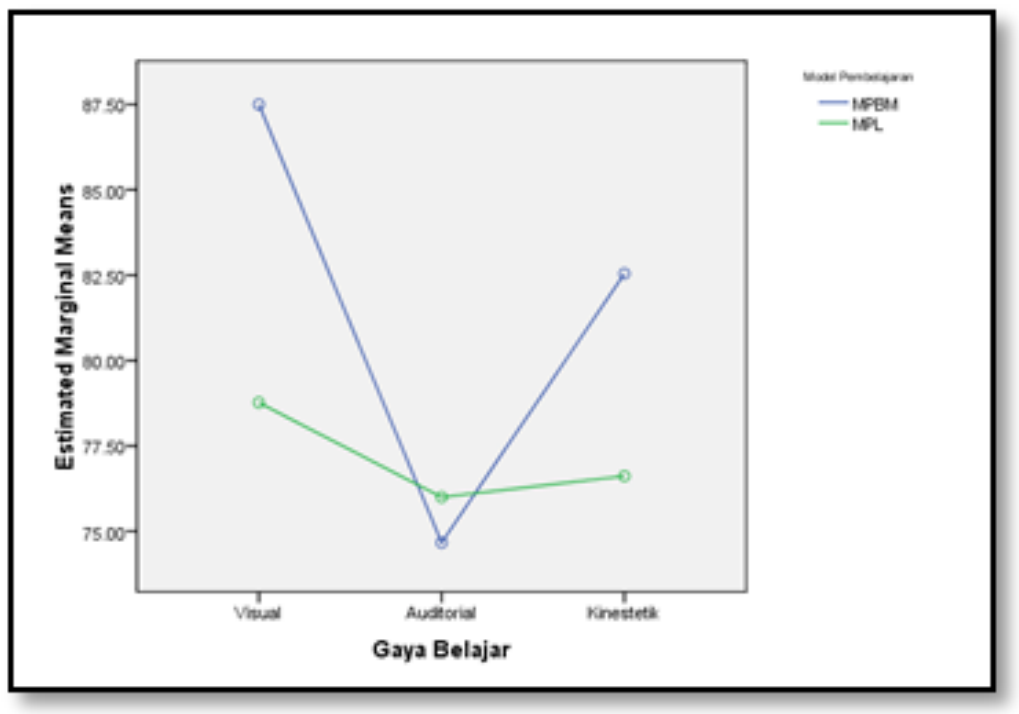

Gambar 1. Pola Interaksi Hasil Belajar

Dapat dilihat bahwa mahasiswa yang memiliki gaya belajar visual pada MPBM lebih tinggi dari pada siswa yang belajar MPL. Hal ini karena, anak bertipe visual lebih teliti terhadap detail, mementingkan penampilan, rapi dan teratur, sehingga akan berpengaruh terhadap hasil belajar membuat pola kerah yang menuntut untuk dapat menganalisa desain dengan baik. Selanjutnya, untuk mahasiswa yang memiliki gaya belajar auditorial pada MPBM lebih rendah daripada MPL. Hal ini karena pada pembelajaran langsung peran guru lebih dominan, sehingga cocok untuk tipe auditorial yang dapat belajar lebih baik dengan 
mendengarkan apa yang dosen katakan. Sedangkan untuk mahasiswa yang memiliki gaya belajar kinestetik pada MPBM lebih tinggi daripada MPL, karena anak bertipe kinestetik lebih mudah menyerap dan memahami informasi dengan cara memperhatikan gambar untuk kemudian belajar memahami suatu materi, serta mereka memiliki kemampuan mengkoordinasi sebuah tim, sehingga cocok pada MPBM.

\section{PENUTUP}

Mengacu pada data hasil penelitian, maka dapat ditarik kesimpulan sebagai berikut: (1) Terdapat perbedaan hasil belajar, antara mahasiswa yang belajar dengan model pembelajaran berdasarkan masalah dan model pembelajaran langsung. Hasil belajar mahasiswa yang belajar menggunakan model pembelajaran berdasarkan masalah, lebih tinggi secara signifikan dibanding hasil belajar siswa yang belajar dengan model pembelajaran langsung pada mata kuliah membuat pola kerah. (2) Terdapat perbedaan hasil belajar, antara mahasiswa memiliki gaya belajar visual, auditorial dan kinestetik. Hasil belajar mahasiswa yang memiliki gaya belajar visual, lebih tinggi secara signifikan dibanding hasil belajar mahasiswa yang memiliki gaya belajar auditorial dan kinestetik pada matakuliah dasar pola membuat pola kerah. (3) Terdapat interaksi antara penggunaan model pembelajaran dan gaya belajar mahasiswa terhadap hasil belajar membuat pola kerah.

Berdasarkan simpulan di atas dapat disarankan, bagi dosen sebaiknya memperhatikan gaya belajar visual masing-masing mahasiswa, agar perbedaan gaya belajar mahasiswa dapat terakomodasi dan dapat memberikan peluang bagi mahasiswa untuk mengembangkan kemampuannya secara maksimal, sehingga mahasiswa dapat belajar lebih aktif, kreatif dan senang belajar.

Dalam menentukan penggunaan model pembelajaran yang tepat dalam proses mengajar, sebaiknya dosen terlebih dahulu mengidentifikasi rata-rata gaya belajar mahasiswa yang ada dalam kelas sehingga dalam menyampaikan materi pelajaran, pemilihan model pembelajaran dapat disesuaikan.

Jika rata-rata mahasiswa memiliki gaya belajar visual dan kinestetik maka penggunaan model pembelajaran berdasarkan masalah tepat diterapkan dalam proses pembelajaran. 
Jika rata-rata mahasiswa memiliki gaya belajar auditorial maka penggunaan model pembelajaran langsung tepat diterapkan dalam proses pembelajaran.

Siswa yang memiliki gaya belajar auditorial dengan hasil belajar rendah, guru dapat menyesuaikan cara mengajarnya dengan gaya belajar mahasiswa, seperti: (1) menggunakan variasi vokal dalam presentasi, (2) setelah tiap segmen pengajaran, minta siswa memberitahu teman disebelahnya satu hal yang dia pelajari, dan (3) mengembangkan dan mendorong mahasiswa untuk memikirkan cara untuk menghafal konsep kunci. Sedangkan mahasiswa yang memiliki gaya belajar kinestetik dengan hasil belajar rendah, dosen dapat menyesuaikan cara mengajarnya dengan gaya belajar mahasiswa, seperti: (1) menggunakan alat bantu saat mengajar untuk menimbulkan rasa ingin tahu dan menekankan konsep-konsep kunci, (2) jika bekerja dengan mahasiswa perseorangan, maka dapat memberikan bimbingan parallel dengan duduk di sebelah mahasiswa, bukan di depan atau dibelakang siswa, dan (3) memberikan penguatan secara pribadi pada mahasiswa setiap hari.

\section{DAFTAR PUSTAKA}

Chen, Bryan H. and Hua-Huei. 2014. "Learning style, sense of community and learning effectiveness in hybrid learning environment". Journal: Interactive Learning Environments, Volume 22, Issue 4, pages 485-496.

Fadly, Aditiya. 2012. "Peningkatan Aktivitas dan Hasil Belajar Siswa melalui Model Pembelajaran Problem Based Learning (PBL)". Jurnal Jurusan Manajemen-Fakultas Ekonomi UM.

Gunawan, Adi W. 2014. Genius Learning Strategy: Petunjuk Praktis Untuk Menerapkan Accelerated Learning. Jakarta: PT. Gramedia Pustaka Utama

Hariadi, Rojib Febrian. 2013. "Pengaruh Gaya Belajar (Visual, Auditorial Dan Kinestetik) Terhadap Prestasi Belajar Dasar-Dasar Pekerjaan Bengkel Elektronika Siswa Kelas X Teknik Elektronika Industri SMK Negeri 2 Pengasih Tahun Ajaran 2012/2013". Jurnal Pendidikan Teknik Elektronika, Vol. 3 No. 2.

Ibrahim, Muslimin. 2010. Dasar-dasar Proses Belajar Mengajar. Surabaya: University Press

Kadir. 2015. Statistika Terapan. Jakarta: Rajawali Press.

Kosasih, E. 2014. Strategi Belajar dan Pembelajaran Implementasi Kurikulum 2013. Bandung: Yrama Widya.

McParland, Monica, Lorraine M Noble, and Gill Livingston. 2004. "The effectiveness of problem-based learning compared to traditional teaching in undergraduate psychiatry". Medical Education, 2004;38:859867.

Nafiah, Yunin Nurun. 2014. "Penerapan Model Problem-Based Learning untuk Meningkatkan Ketrampilan Berpikir Kritis dan Hasil Belajar Siswa SMK Islam Terpadu Smart Informatika Surakarta". Jurnal Pendidikan Vokasi, Vol 4, No 1. 2014. 
Nur, Mohamad. 2008. Model Pembelajaran Langsung. Surabaya: Pusat Sains dan Matematika Sekolah UNESA.

Nur, Mohamad. 2011. Model Pembelajaran Berdasarkan Masalah. Surabaya: Pusat Sains dan Matematika Sekolah UNESA

Nurlaela, Luthfiyah. 2010. Model Pembelajaran, Gaya Belajar, Kemampuan Membaca, dan Hasil Belajar. Surabaya: Unesa University Press

Rachmawati, Zulfakria. 2013. "Pengaruh Model Pembelajaran Berdasarkan Masalah Dan Gaya Belajar (Visual, Auditori Dan Kinestetik) Terhadap Hasil Belajar Siswa Pada Mata Diklat Rangkaian Listrik Di Smkn 1 Cerme Gresik". Jurnal Pendidikan Teknik Elektro, Vol 2 No 2.

Rusman. 2010. Model-model Pembelajaran: Mengembangkan Profesionalisme Guru. Jakarta: Rajawali Pers.

Sardiman. 2012. Interaksi \& Motivasi Belajar Mengajar. Jakarta: Rajawali Pers.

Sujarwo. 2012. "Pengaruh Metode Pembelajaran Dan Gaya Belajar Terhadap Hasil Belajar". Majalah ilmu pendidikan No. 01/Th.XIX/Juni 2012.

Sungur, Semra dan Ceren. 2006. "Effects of Problem-Based Learning and Traditional Instruction on Self-Regulated Learning". The Journal of Educational Research, Vol. 99 (No. 5), May/June 2006.

Trianto. 2007. Model-model Pembelajaran Inovatif Berorientasi Konstruktivistik. Jakarta: Prestasi pustaka.

Tuckman, Bruce W. 1988. Conducting Educational Research - Third Edition. United State of America: Harcourt Brace Jovanovic.

Wulandari, Bekti 2013. “Pengaruh Problem-Based Learning Terhadap Hasil Belajar Ditinjau Dari Motivasi Belajar PLC di SMK". Jurnal Pendidikan Vokasi. Vol 3, Nomor 2, Juni 2013. 